\title{
Acquired protection in Atlantic salmon Salmo salar parr and post-smolts against pancreas disease
}

\author{
Gillian Houghton \\ SOAFD Marine Laboratory, PO Box 101, Victoria Road, Aberdeen AB9 8DB, United Kingdom
}

\begin{abstract}
Experimental infection of Atlantic salmon Salmo salar parr and post-smolts with pancreas disease infective kidney homogenate induced a highly significant protection against the disease following exposure to challenge infections at either $3,4,7$ or 9 mo after the initial infection. Protection was maintained in fish infected as parr and exposed to a challenge infection following smolting and sea water transfer. A carrier status was not demonstrated in immune fish since homogenates of kidneys taken 1 and 2 wk post-challenge were not infective, unlike homogenates of kidneys from non-immune fish.
\end{abstract}

KEY WORDS: Pancreas disease Acquired protection Atlantic salmon

\section{INTRODUCTION}

Pancreas disease (PD) has been reported to occur in farmed Atlantic salmon in Scotland, Ireland, Norway and the western USA (Munro et al. 1984, Kent \& Elston 1987, Poppe et al. 1989, Murphy et al. 1992) and more recently in Spain and France (McVicar pers. comm.). The disease was first recorded in Scotland in 1976 and results in the total necrosis of the acinar cells of the exocrine pancreas although the endocrine pancreas appears to be unaffected (Munro et al. 1984, McVicar 1987). The disease only occurs in the sea water phase of salmon growth and can lead to significant economic loss.

McVicar (1987) suggested the disease was caused by an infectious agent, possibly of viral aetiology, but numerous attempts to culture the agent have failed. However, experimental transmission of the disease is now well established (McVicar 1990, Raynard \& Houghton 1993).

To date there has been no experimental evidence that fish can acquire protection to PD, although it has been suggested that this may occur on farms (McVicar 1987). The aims of the present work were to investigate acquired protection of Atlantic salmon parr and post-smolts to PD following experimental infection and whether protection can be maintained following the parr-to-smolt transformation and subsequent sea water transfer. In addition, the carrier status of recovered fish was also investigated.

\section{MATERIALS AND METHODS}

Fish. Atlantic salmon Salmo salar were maintained at the Fish Cultivation Unit of the Marine Laboratory, Aultbea, Wester Ross, Scotland, UK. Salmon parr were obtained either from a commercial fish farm (Expts 1 $\& 2$ ) or reared at the Fish Cultivation Unit as were the post-smolts. The Fish Cultivation Unit has a history of being free of $\mathrm{PD}$ and infectious pancreatic necrosis virus (IPNV). Furthermore, experimental fish were tested prior to experimentation, to ensure the absence of IPNV. Samples were also taken for histology to ensure fish were free of PD.

Salmon parr were maintained in $1 \mathrm{~m}$ diameter tanks containing $350 \mathrm{l}$ of water supplied from an enclosed freshwater loch at a rate of $10 \mathrm{lmin}^{-1} \operatorname{tank}^{-1}$. Salmon post-smolts were maintained in either $2 \mathrm{~m}^{2}$ tanks (Expt 3) or $1 \mathrm{~m}$ diameter tanks (Expts 4 \& 5) containing sea water, supplied via a settling reservoir, from Loch Ewe at a rate of approximately $15 \mathrm{l} \mathrm{min}^{-1}$ for the 
$1 \mathrm{~m}$ tanks and at a rate of $20 \mathrm{l} \mathrm{min}^{-1}$ for the $2 \mathrm{~m}$ tanks. The water temperatures were seasonally variable, ranging from 4 to $20^{\circ} \mathrm{C}$ in fresh water and from 10 to $15^{\circ} \mathrm{C}$ in sea water, and are recorded in the results. For freshwater challenges, heated water at $14^{\circ} \mathrm{C}$ was used for the duration of the challenge. Fish were fed a standard commercial diet by automatic feeders to satiation (mainstream diets; BP Nutrition). Salmon parr were allowed to acclimate in tanks for $4 \mathrm{wk}$ prior to experimentation. Post-smolts were allowed to acclimate in tanks for $5 \mathrm{wk}$ post sea water transfer. Prior to handling, freshwater parr were anaesthetised in ethyl-4-aminobenzoate (benzocaine; $\mathrm{BDH}, \mathrm{UK}$ ) dissolved in ethanol and post-smolts were anaesthetised in 3-aminobenzoic acid ethyl ester (MS222; Sigma, UK).

Histology. For histological examination of the pancreas, pyloric caeca with pancreas were fixed in $20 \%$ buffered formol saline, embedded in paraffin wax and $5 \mu \mathrm{m}$ sections cut and stained with haematoxylin and eosin. Assessment of PD pathology was carried out according to Raynard \& Houghton (1993).

Preparation of kidney homogenates. Negative or positive kidney homogenates were prepared in phosphate buffered saline (PBS), pH 7.2, without calcium and magnesium (Gibco, UK) following the method of Raynard \& Houghton (1993). The dose used was determined by measuring the protein concentration following procedure 609-A (Sigma).
The term 'negative' kidney homogenate refers to a kidney homogenate made from the kidneys of fish which have not previously been infected with PD. The term 'positive' kidney homogenate refers to a kidney homogenate made from the kidneys of fish which have been experimentally infected with PD, and which was known by experimentation to be capable of transmitting PD upon injection into naive fish (see Raynard \& Houghton 1993). All kidney homogenates were shown to be negative for IPNV.

Experimental procedure. Five experiments were performed to investigate whether Atlantic salmon develop immunity to PD. In Expts 1 \& 2, fish were exposed to both primary and challenge infections of the disease as fresh water parr. In Expt 3, fish were exposed to both a primary and a challenge infection of the disease as post-smolts in sea water. In Expts 4 \& 5 , fish were exposed to a primary infection of the disease as freshwater parr and to a challenge infection following smolting and sea water transfer. Details of the experimental procedure are shown in Fig. 1.

Freshwater parr (Expts 1 \& 2). Mean fish weights and water temperatures at the start of each experiment were as follows: Expt 1, mean weight $37.6 \pm 5.5$ (SD) g, temperature $20^{\circ} \mathrm{C}$ i Expt 2, mean weight $40.5 \pm 9.0 \mathrm{~g}$, temperature $14^{\circ} \mathrm{C}$.

In Expt 1, for the primary infection, 500 fish (250 tank $\mathrm{k}^{-1}$ ) were injected intraperitoneally (i.p.) with positive kidney homogenate and 500 control fish
Time (weeks)

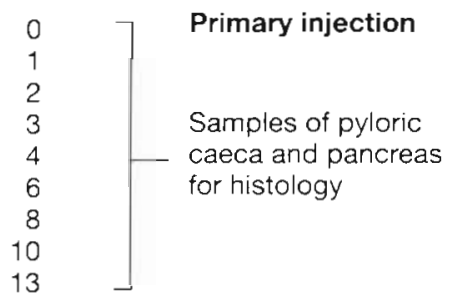

Challenge injections

3 months (Expts 1 \& 2)

4 months (Expt 3)

7 months (Expt 5)

9 months (Expts 4 \& 5)

\section{Time (weeks)}

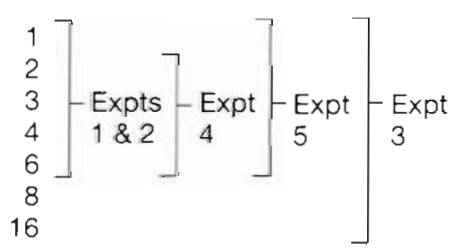

\section{Procedure}

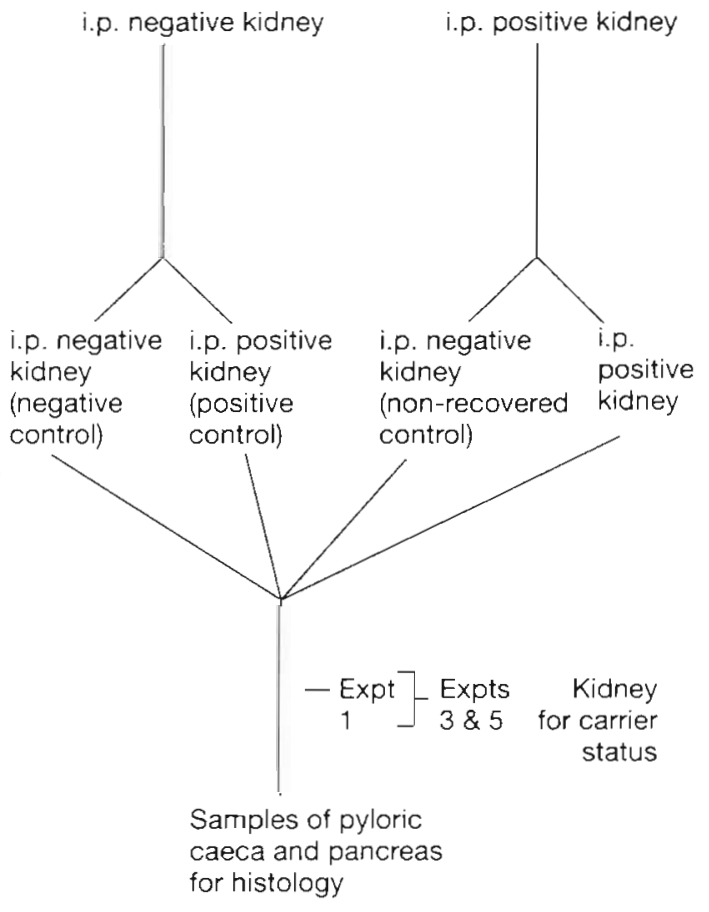

Fig. 1. Experimental protocol used to investigate acquired protection in Atlantic salmon Salmo salar parr and post-smolts to pancreas disease. Fish were injected intraperitoneally (i.p.) 
(250 tank ${ }^{-1}$ ) were injected with negative kidney homogenate at a protein concentration of $6 \mu \mathrm{g} \mathrm{g}^{-1}$ body weight. In Expt 2, the number of fish in each group was $550\left(275 \operatorname{tank}^{-1}\right)$ injected at a protein concentration of $3 \mu \mathrm{g} \mathrm{g}^{-1}$ body weight.

Following injection of positive or negative kidney homogenate, samples of pyloric caeca and pancreas were taken and processed for histology at the following weeks post-infection: $0,1,2,3,4,6,8,10,13$ and immediately prior to administration of the challenge. The number of fish sampled from each group at each time interval was 15 fish for Expt 1 and 10 fish for Expt 2 .

To test for protective immunity, fish were administered a second injection of positive kidney homogenate at the same dose used for the primary infection, 3 mo following the primary infection. For the challenge, the water temperature was maintained at $14^{\circ} \mathrm{C}$. At challenge, the negative control group and the PD treated group of fish were each divided into 2 further groups of equal number ( $\mathrm{n}=160$, Expt $1 ; n=190$, Expt 2). One of the groups of negative controls was injected with negative kidney homogenate and the other with positive kidney homogenate. Similarly, one of the groups of PD treated fish was injected with positive kidney homogenate and the other with negative kidney homogenate (Fig. 1). In addition, in Expt 2, a further control group was included of fish $(n=115)$ which were untreated for the primary infection but administered positive kidney homogenate at challenge.

Following challenge, samples of pyloric caeca and pancreas were taken and processed for histology from fish in each group at $1,2,3$ and 6 wk post-challenge. The numbers of fish sampled are indicated in the results.

Post-smolts (Expt 3). Mean fish weight and water temperature at the start of the experiment were: weight $38.9 \pm 6.4 \mathrm{~g}$, temperature $10^{\circ} \mathrm{C}$

For the primary infection, 450 fish $\left(450 \operatorname{tank}^{-1}\right)$ were injected i.p. with positive kidney homogenate and 450 control fish (450 $\operatorname{tank}^{-1}$ ) were injected with negative kidney homogenate. Due to the variability in transmitting PD in sea water (Raynard \& Houghton 1993), a higher dose of $30 \mu \mathrm{g} \mathrm{g}^{-1}$ body weight was administered.

Following injection of positive or negative kidney homogenate, samples of pyloric caeca and pancreas were taken and processed for histology at the following weeks post-infection: $0,1,2,3,4,6,13$ and immediately prior to administration of the challenge. The number of fish sampled from each group at each time was 20 .

Fish were challenged 4 mo following the primary infection with a dose of $10 \mu \mathrm{g} \mathrm{g}^{-1}$ body weight and at a water temperature of $12{ }^{\circ} \mathrm{C}$. At challenge, the negative controls and $\mathrm{PD}$ treated fish were each divided into
2 further groups of equal number ( $n=120$ ) and injected as described above for the parr (Fig. 1).

Following challenge, samples of pyloric caeca and pancreas were taken and processed for histology from fish in each group at $1,2,3,4,8$ and 16 wk postchallenge. The numbers of fish sampled are indicated in the results.

Parr-to-smolt transformation (Expts 4 \& 5). Mean fish weights and temperatures at the start of each experiment were as follows: Expt 4, mean weight $11.5 \pm$ $2.3 \mathrm{~g} \mathrm{SD}$, temperature $14^{\circ} \mathrm{C}$; Expt 5 , mean weight $19.9 \pm 1.9 \mathrm{~g} \mathrm{SD}$, temperature $14^{\circ} \mathrm{C}$.

In Expt 4, for the primary infection 700 fish (350 $\operatorname{tank}^{-1}$ ) were injected i.p. with positive kidney homogenate and 700 control fish (350 tank $\left.\mathrm{k}^{-1}\right)$ were injected with negative kidney homogenate at a protein concentration of $3 \mu \mathrm{g} \mathrm{g}^{-1}$ body weight. In Expt 5, 1000 fish in each group $\left(250 \operatorname{tank}^{-1}\right)$ were injected at a protein concentration of $10 \mu \mathrm{g} \mathrm{g}^{-1}$ body weight.

Following injection of positive or negative kidney homogenate, samples of pyloric caeca and pancreas were taken and processed for histology at the following weeks post-infection: $0,1,2,3,4,6,8,10,13$ and immediately prior to challenge. The number of fish sampled from each group at each time was 10 fish for Expt 4 and 20 fish for Expt 5

In these 2 experiments, parr were transferred to sea water after smolting. These fish were then challenged after acclimation and recommencement of feeding. For Expt 4, an equal number of negative controls ( $\mathrm{n}=560$ ) and PD treated $(n=560)$ fish were transferred to sea water 8 mo following the primary infection and challenged 1 mo later with a dose of $10 \mu \mathrm{g} \mathrm{g}^{-1}$ body weight and at a water temperature of $10^{\circ} \mathrm{C}$. Prior to challenge, half of the fish were lost from each group due to a blockage of the sea water inlet pipe. At challenge, the negative controls and PD treated fish were divided into 2 further groups of equal number $(\mathrm{n}=140$ ) and challenged as described above. An additional group of fish ( $n=65$ ) were included which were untreated for the primary infection but administered positive kidney homogenate at challenge. Samples of pyloric caeca and pancreas were taken and processed for histology from fish in each group at 2, 3 and 6 wk post-challenge, the number of fish sampled being indicated in the results.

In Expt 5, an equal number of negative controls $(n=750)$ and $P D$ treated fish $(n=750)$ were transferred to sea water 6 mo following the primary infection. Some mortalities occurred due to fish not recommencing feeding. Half of the fish were challenged after 1 mo and the other half after 3 mo in sea water, at a dose of $10 \mu \mathrm{g} \mathrm{g}^{-1}$ body weight and a water temperature of $12{ }^{\circ} \mathrm{C}$. At challenge, the negative controls and PD treated fish were divided into 2 further groups of equal number $(n=180$ for the 1 mo challenge; $n=155$ for the 
3 mo challenge), and challenged as described above. Samples of pyloric caeca and pancreas were taken from fish in each group at 1, 2, 3, 4 and 6 wk postchallenge for the 1 mo challenge and at 1, 2, 3 and 6 wk post-challenge for the 3 mo challenge. The numbers of fish sampled are indicated in the results.

All fish injected with negative kidney homogenate were kept in separate tanks from fish injected with positive kidney homogenate. Duplicate tanks were used in Expt 5.

Carrier status. In order to assess whether fish which have recovered from a primary infection and whether potentially immune fish were still infective and thus could act as carriers of the disease, kidney from each of the groups of fish (donors) in Expts 1, 3 \& 5 were collected and tested for infectivity following challenge. Pyloric caeca and pancreas were also taken from these same fish for histology to assess pancreas pathology. In Expt 1, kidneys were taken from fish at 1 wk postchallenge, when non-immune fish are known to be highly infectious (Raynard \& Houghton 1993). In Expts $3 \& 5$, to ensure that any absence of infectivity in immune fish was not due to a temporary suppression of the disease-causing agent, kidneys were taken at both 1 and 2 wk post-challenge. Kidneys were taken from 15 fish in each group in Expts $1 \& 3$ and from 10 fish in each group in Expt 5, homogenised in PBS following the method of Raynard \& Houghton (1993) and stored in liquid nitrogen. Homogenates of these kidneys were then injected i.p. into recipient salmon parr at a dose of either 20 or $30 \mu \mathrm{g}$ protein $\mathrm{g}^{-1}$ body weight. Samples of pyloric caeca and pancreas were taken from 10 recipient fish in each group at the following weekly intervals: from Week 1 to 7 (Expt 1), Week 1 to 5 (Expt 3), and Week 1 to 4 (Expt 5) as indicated in the results to assess pancreas pathology.

Statistical analyses. Statistical analyses using the $\chi^{2}$ calculation were performed to test levels of significance.

\section{RESULTS}

\section{Terminology}

'Early PD': vacuolation and rounding of the acinar cells over the whole exocrine tissue. Absence of zymogen from many cells

'Acute PD': total loss of the acinar cells of the exocrine pancreas.

'Chronic PD': total absence of acinar cells, fibrotic pancreas tissue. Failure to regenerate pancreas.

\section{Freshwater parr}

Following exposure to a primary infection of $\mathrm{PD}$, pathology levels of up to $90 \%$ occurred in the samples of fish which were examined (see Fig. 2a, b). For Expt 1 (Fig. 2a), where the temperature at the start of the ex-
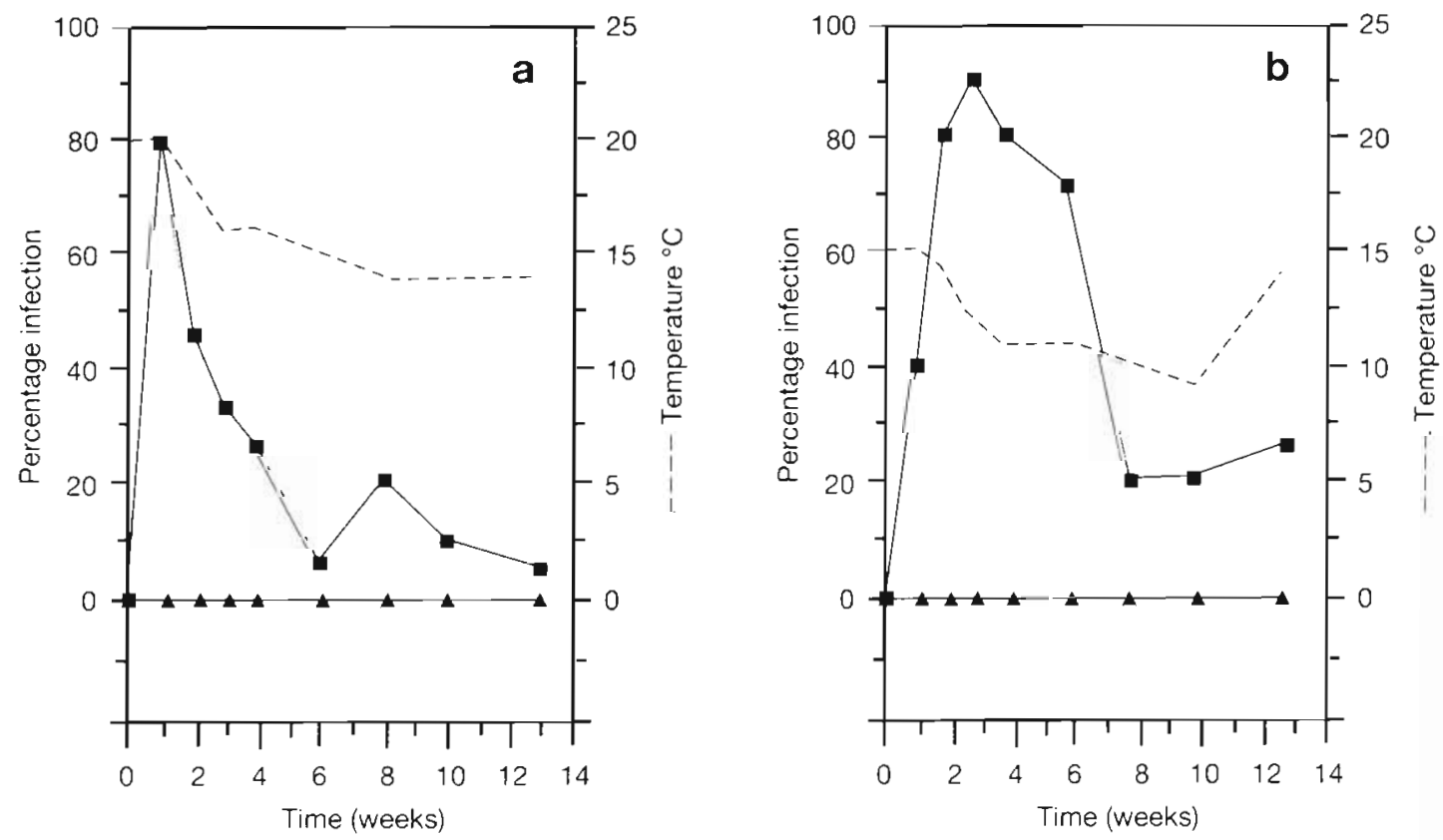

Fig. 2. Salmo salar. Percentage infection with time for Atlantic salmon parr injected with negative (A) or positive homogenate. (a) 15 fish per group (Expt 1), (b) 10 fish per group (Expt 2) 
Table 1. Salmo salar. Percentage of Atlantic salmon parr with pancreas disease pathology at various weeks following exposure to a challenge infection $3 \mathrm{mo}$ after a primary infection; Expt 1 . Results in parentheses are from Expt 2 . Temperature $14^{\circ} \mathrm{C}$. E: early PD; C: chronic PD; nt: not tested

\begin{tabular}{|c|c|c|c|c|c|c|}
\hline \multicolumn{2}{|c|}{$\begin{array}{l}\text { Kidney homogenate } \\
\text { injected at: }\end{array}$} & \multirow[t]{2}{*}{$\begin{array}{c}\text { Pre-challenge } \\
\text { sample }\end{array}$} & \multicolumn{4}{|c|}{ Percentage $\mathrm{PD}$, post-challenge } \\
\hline Primary & Challenge & & $1 \mathrm{wk}$ & $2 w k$ & 3 wk & $6 \mathrm{wk}$ \\
\hline Negative & Negative & $0(0)$ & $0(0)$ & $0(0)$ & $0(0)$ & $0(0)$ \\
\hline Positive & Negative & $5(25) \mathrm{C}$ & $8(20) \mathrm{C}$ & $3(25) \mathrm{C}$ & $5(26) \mathrm{C}$ & $0(13) \mathrm{C}$ \\
\hline Positive & Positive & $5(25) \mathrm{C}$ & $4(12) \mathrm{C}$ & $15(25) \mathrm{C}$ & $6(20) \mathrm{C}$ & $8(22) \mathrm{C}$ \\
\hline Negative & Positive & $0(0)$ & $40 \mathrm{E}(48 \mathrm{E})$ & $53(52)$ & $68(72)$ & $15(40)$ \\
\hline Untreated & Positive & nt $(0)$ & nt (nt) & nt $(80)$ & nt (92) & nt (nt) \\
\hline \multicolumn{2}{|c|}{ No. of fish per group } & $20(20)$ & $25(25)$ & $45(50)$ & $50(65)$ & $20(30)$ \\
\hline
\end{tabular}

periment was relatively high $\left(20^{\circ} \mathrm{C}\right)$, peak pathology occurred 1 wk after the administration of positive kidney homogenate, followed by a fairly rapid recovery of fish from the disease. Five percent of fish did not recover but developed chronic PD. In Expt 2 (Fig. 2b) where water temperatures at the start of the experiment were lower $\left(15^{\circ} \mathrm{C}\right)$, peak pathology occurred later (Week 3) and recovery was less rapid. Furthermore, there was a higher percentage of fish (25\%) in the infected group which did not recover, but developed chronic PD

Following exposure to a challenge infection of positive kidney homogenate, a high degree of protection was found in fish previously exposed to the disease (Table 1). At 1 wk post-challenge, there was already an indication that the fish were protected, unlike fish which had not previously been exposed to the disease but which received a primary infection at the time of challenge. These fish showed signs of early PD pathology (40\% of fish in Expt 1 and $48 \%$ in Expt 2 ). At 2 and $3 \mathrm{wk}$ post-challenge, fish previously exposed to the disease still showed a high level of protection which was significantly different ( $\mathrm{p}<0.001)$ from fish which had not been previously exposed to the disease and which had reached acute PD levels of up to $72 \%$. In addition, a further group of fish was included for the repeat experiment which had received no primary treatment but which were injected with positive kidney material for the challenge. These fish reached acute PD levels of $92 \%$. By $6 \mathrm{wk}$ post-challenge, recovery from the disease was evident in the fish not having previously been exposed to the disease. Although some fish within the previously exposed group showed a chronic PD pathology, this was comparable with the group of fish which received a primary infection of PD but were injected with negative kidney material at the time of challenge, indicating they were non-recovered fish. As shown in Fig. 2a, b, at Week 13 following a primary infection there were still fish within each group showing non-recovery
(5\%, Expt 1; $25 \%$, Expt 2). No mortalities due to PD occurred.

\section{Post-smolts}

Following exposure to a primary infection, peak pathology was evident at Week 2 with up to $40 \%$ of fish sampled having acute PD (Fig. 3). This was followed by a full recovery from the disease.

Results shown in Table 2 indicate that fish which had previously been exposed to an infection of PD and subsequently challenged showed a very high level of protection, with only $4 \%$ of fish within this group demon-

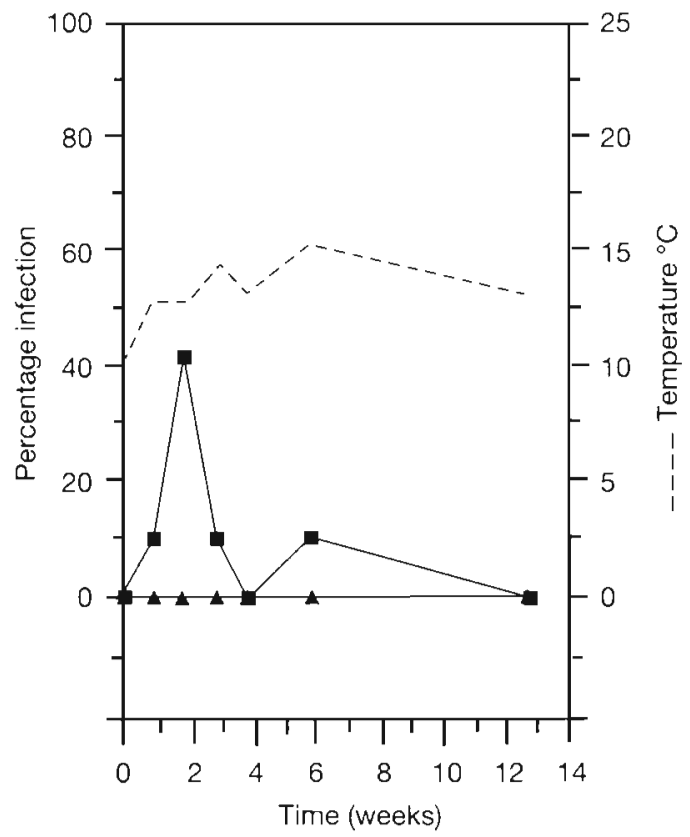

Fig. 3. Salmo salar. Percentage infection with time for Atlantic salmon post-smolts injected with negative $(\boldsymbol{A})$ or positive kidney homogenate. Twenty fish per group (Expt 3) 
Table 2. Salmo salar. Percentage of Atlantic salmon post-smolts with pancreas disease pathology at various weeks following exposure to a challenge infection 4 mo after a primary infection; Expt 3 . Temperature $12^{\circ} \mathrm{C}$. E: early PD

\begin{tabular}{|c|c|c|c|c|c|c|c|c|}
\hline \multicolumn{2}{|c|}{$\begin{array}{c}\text { Kidney homogenate } \\
\text { injected at: }\end{array}$} & \multirow[t]{2}{*}{$\begin{array}{l}\text { Pre-challenge } \\
\text { sample }\end{array}$} & \multicolumn{6}{|c|}{ Percentage PD, post-challenge } \\
\hline Primary & Challenge & & $1 \mathrm{wk}$ & $2 w k$ & $3 w \mathrm{k}$ & $4 \mathrm{wk}$ & $8 w k$ & $16 \mathrm{wk}$ \\
\hline Negative & Negative & 0 & 0 & 0 & 0 & 0 & 0 & 0 \\
\hline Positive & Negative & 0 & 0 & 0 & 0 & 0 & 0 & 0 \\
\hline Positive & Positive & 0 & 0 & 4 & 0 & 0 & 0 & 0 \\
\hline Negative & Positive & 0 & 0 & $20(40 E)$ & 68 & 60 & 20 & 0 \\
\hline \multicolumn{2}{|c|}{ No. of fish per qroup } & 20 & 25 & 25 & 40 & 10 & 10 & 10 \\
\hline
\end{tabular}

strating PD pathology. This was significantly different ( $p<0.001$ ) from the positive controls where up to $68 \%$ of fish showed PD pathology by 3 wk post-challenge. No mortalities due to PD occurred.

\section{Parr-to-smolt transformation}

Following exposure of salmon as freshwater parr to a primary infection of $\mathrm{PD}$, the disease prevalence was up to $65 \%$ in the samples of fish which were examined in Expts 4 \& 5 (Fig. 4a, b). For Expt 4 (Fig. 4a), the temperature at the start of the experiment was $14^{\circ} \mathrm{C}$ but fell to $5^{\circ} \mathrm{C}$, with peak pathology occurring $4 \mathrm{wk}$ after administration of positive kidney homogenate. This was followed by a fairly slow recovery, with $20 \%$ of fish failing to recover and demonstrating a chronic $P D$ at Week 13. In Expt 5 (Fig. 4 b), a temperature of $14{ }^{\circ} \mathrm{C}$ was maintained for the first $6 \mathrm{wk}$ after infection. A peak prevalence of PD of $65 \%$ occurred in Week 2 and $10 \%$ of fish failed to recover, developing chronic PD at Week 13.

Following exposure to a challenge infection of positive kidney homogenate, a very high level of protection was shown to occur in fish previously exposed to the disease in both Expt 4 \& 5 (Tables $3 \& 4$ ). In Expt 4 (Table 3), fish were challenged 9 mo after primary exposure, and $11 \%$ of fish within this group showed PD pathology. This was comparable with the group of fish which received a primary infection of PD and negative kidney material at the time of challenge, indicating they were non-recovered fish having chronic PD. In
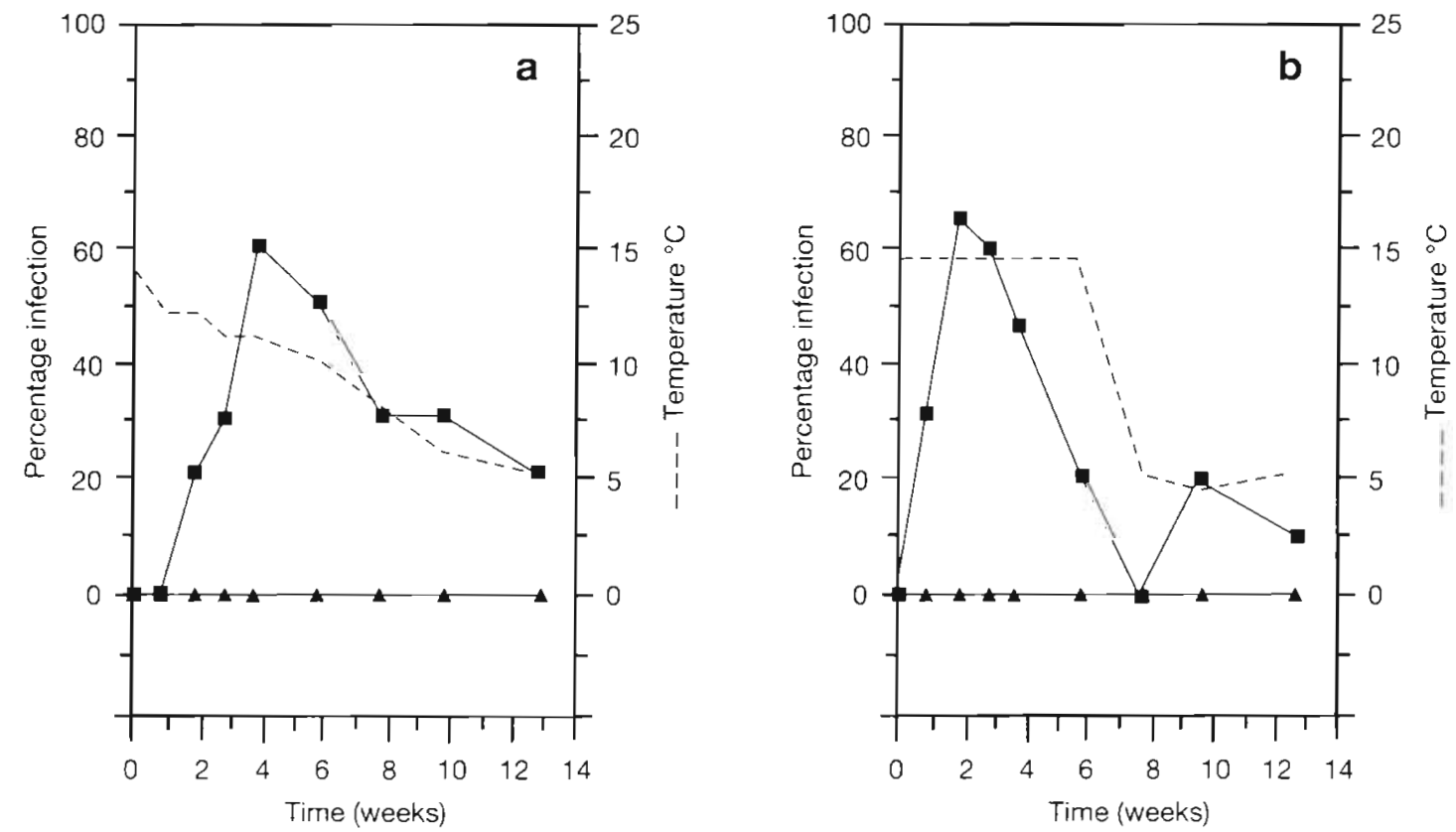

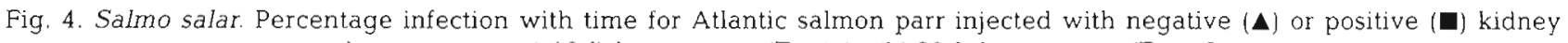
homogenate. (a) 10 fish per group (Expt 4), (b) 20 fish per group (Expt 5) 
Table 3. Salmo salar. Percentage of Atlantic salmon post-smolts with pancreas disease pathology at various weeks following exposure to a challenge infection 9 mo after a primary infection (1 mo after sea water transfer); Expt 4 . Results in parentheses are for fish which failed to smolt and were challenged in fresh water. Temperature $10^{\circ} \mathrm{C}$. E: early PD; $\mathrm{C}$ : chronic PD; $\mathrm{nt}$ : not tested

\begin{tabular}{|c|c|c|c|c|c|}
\hline \multicolumn{2}{|c|}{$\begin{array}{l}\text { Kidney homogenate } \\
\text { injected at: }\end{array}$} & \multirow[t]{2}{*}{$\begin{array}{l}\text { Pre-challenge } \\
\text { sample }\end{array}$} & \multicolumn{3}{|c|}{ Percentage PD, post-challenge } \\
\hline Primary & Challenge & & $2 w k$ & $3 w \mathrm{k}$ & $6 \mathrm{wk}$ \\
\hline Negative & Negative & 0 & $0(0)$ & $0(0)$ & $0(0)$ \\
\hline Positive & Negative & $10 \mathrm{C}$ & $0(0)$ & $4(18) \mathrm{C}$ & $O(n t)$ \\
\hline Positive & Positive & $10 \mathrm{C}$ & $O(10) C$ & $11(12) \mathrm{C}$ & 0 (nt) \\
\hline Negative & Positive & 0 & $60(90)$ & $77(74)$ & 12 (nt) \\
\hline Untreated & Positive & 0 & nt (nt) & $68(\mathrm{nt})$ & 0 (nt) \\
\hline \multicolumn{2}{|c|}{ No. of fish per group } & 10 & 10 & 35 & 20 \\
\hline
\end{tabular}

the positive controls, up to $77 \%$ of the fish showed PD pathology by 3 wk post-challenge, which was significantly different $(p<0.001$ ) from the protected group. At the same time at which the post-smolts were challenged in sea water, non-smolted fish which were retained in fresh water were also exposed to a challenge infection of PD (Table 3). A high level of protection was also seen within this group of fish, with only $12 \%$ of the fish previously exposed to PD exhibiting pathology, comparable with a non-recovery level of $18 \%$. This was significantly different ( $p<0.001$ ) from the positive control groups, in which up to $90 \%$ of fish developed PD pathology by 2 wk post-challenge. Some mortalities occurred in the chronically infected S2 parr due to a Pseudomonas infection.

In Expt 5, where fish were challenged 7 mo after primary exposure to PD (Table 4), only a maximum of $10 \%$ of fish within this group showed PD pathology. This was comparable with a level of $10 \%$ in the controls for the non-recovered, chronically diseased fish. In contrast, up to $63 \%$ of fish in the positive controls showed PD pathology, with peak prevalence occurring at $3 \mathrm{wk}$ post-challenge. This was significantly different $(p<0.001)$ from the protected group.
In the second group of fish from this population (Expt 5), which were challenged 9 mo after the primary infection of PD (Table 4), a high level of protection occurred, with only $5 \%$ of fish showing PD pathology comparable with the level of $5 \%$ in the controls for the non-recovered, chronically diseased fish. In contrast, up to $66 \%$ of fish in the positive control group developed PD pathology, with peak prevalence occurring at 2 wk post-challenge. This was significantly different $(p<0.001)$ from the protected group. No mortalities due to PD occurred.

None of the fish injected with negative kidney homogenate showed any pancreas pathology, confirming the absence of PD and IPNV from the experimental site.

\section{Carrier status}

The results in Tables 5, 6 \& 7 show that homogenates of kidneys taken from parr and postsmolts given a primary injection of positive kidney and shown to have recovered from the disease (with the exception of Expt 5 where $10 \%$ had become chronically infected) were not infective. Kidney homo-

Table 4. Salmo salar. Percentage of Atlantic salmon post-smolts with pancreas disease pathology at various weeks following exposure to a challenge infection 7 mo after a primary infection ( 1 mo after sea water transfer); temperature $13.5^{\circ} \mathrm{C}$. Results in parentheses are for fish exposed to a challenge infection 9 mo after a primary infection ( 3 mo after sea water transfer); temperature $12^{\circ} \mathrm{C}$. Expt 5. E: early PD; C; chronic PD; nt: not tested

\begin{tabular}{|lccccccc|}
\hline \multicolumn{2}{|c}{$\begin{array}{c}\text { Kidney homogenate } \\
\text { injected at: }\end{array}$} & $\begin{array}{c}\text { Pre-challenge } \\
\text { sample }\end{array}$ & \multicolumn{4}{c|}{ Percentage PD, post-challenge } \\
Primary & Challenge & & $1 \mathrm{wk}$ & $2 \mathrm{wk}$ & $3 \mathrm{wk}$ & $4 \mathrm{wk}$ & $6 \mathrm{wk}$ \\
\hline Negative & Negative & $0(0)$ & $0(0)$ & $0(0)$ & $0(0)$ & $0(0)$ & $0(0)$ \\
Positive & Negative & $10(10) \mathrm{C}$ & $10(5) \mathrm{C}$ & $10(5) \mathrm{C}$ & $9(5) \mathrm{C}$ & $8 \mathrm{C}(\mathrm{nt})$ & $0(6 \mathrm{C})$ \\
Positive & Positive & $10(10) \mathrm{C}$ & $10(5) \mathrm{C}$ & $6(5) \mathrm{C}$ & $3(5) \mathrm{C}$ & $10 \mathrm{C}(\mathrm{nt})$ & $10(4) \mathrm{C}$ \\
Negative & Positive & $0(0)$ & $20(55) \mathrm{E}$ & $40(66)$ & $63(60)$ & $53(\mathrm{nt})$ & $20(5)$ \\
No. of fish per group & $10(10)$ & $20(25)$ & $30(40)$ & $80(50)$ & $40(\mathrm{nt})$ & $10(40)$ \\
\hline
\end{tabular}


genates taken from parr and post-smolts given both primary and challenge injections of positive kidney homogenate were also shown not to be infective. In contrast, the kidneys taken from fish receiving negative kidney homogenate for the primary injection and positive kidney homogenate at challenge were highly infective, with up to $90 \%$ of recipient fish developing pancreas pathology. This was comparable with positive controls infected with a known PD-infectedkidney homogenate, where also up to $90 \%$ of fish developed PD pathology. The peak pathology varied with each experiment depending on the temperatures at which the experiments were performed (see Tables 5,6 \& 7)

Table 5. Salmo salar. Percentage of salmon parr $(19.6 \pm 2.8 \mathrm{~g})$ with pancreas disease pathology at various weeks following i.p. injection of kidney homogenate taken from non-immune and immune parr (Expt 1), injected at a dose of $20 \mu \mathrm{g} \mathrm{g} \mathrm{g}^{-1}$ body weight, temperature $7.5^{\circ} \mathrm{C}$. Values in parentheses are results using a dose of $30 \mu \mathrm{g} \mathrm{g}^{-1}$ body weight, temperature $14^{\circ} \mathrm{C}$. Ten fish sampled per group per week. E: early PD; C: chronic PD

\begin{tabular}{|c|c|c|c|c|c|c|c|c|c|}
\hline \multicolumn{2}{|c|}{$\begin{array}{l}\text { Kidney homogenate } \\
\text { injected at: }\end{array}$} & \multirow[t]{2}{*}{$\% \mathrm{PD}^{\mathrm{a}}$} & \multicolumn{7}{|c|}{ Percentage PD, post-injection } \\
\hline Primary & Challenge & & $1 \mathrm{wk}$ & $2 \mathrm{wk}$ & $3 w k$ & $4 \mathrm{wk}$ & $5 \mathrm{wk}$ & $6 \mathrm{wk}$ & $7 \mathrm{wk}$ \\
\hline Neçative & Negative & 0 & $0(0)$ & $0(0)$ & $0(0)$ & $0(0)$ & 0 & 0 & 0 \\
\hline Positive & Negative & 0 & $0(0)$ & $0(0)$ & $0(0)$ & $0(0)$ & 0 & 0 & 0 \\
\hline Positive & Positive & $10 \mathrm{C}$ & $0(0)$ & $0(0)$ & $0(0)$ & $0(0)$ & 0 & 0 & 0 \\
\hline Negative & Positive & $40 \mathrm{E}$ & $0(0)$ & $0(80)$ & $20 E(60)$ & $30(50)$ & 70 & 60 & 60 \\
\hline \multicolumn{2}{|c|}{ Positive control } & & $0(0)$ & $0\{80\}$ & $20 \mathrm{E}(80)$ & $20(50)$ & 60 & 60 & 30 \\
\hline
\end{tabular}

Table 6. Salmo salar. Percentage of salmon parr $(10.0 \pm 2.1 \mathrm{~g})$ with pancreas disease pathology at various weeks following i.p. injection of kidney homogenate taken from non-immune and immune post-smolts (Expt 3), injected at a dose of $30 \mu \mathrm{g} \mathrm{g} \mathrm{g}^{-1}$ body weight. Results in parentheses are from kidneys taken $2 \mathrm{wk}$ post-challenge. Temperature $14^{\circ} \mathrm{C}$. Ten fish sampled per group per wk

\begin{tabular}{|lccccccc}
\hline \multicolumn{2}{c}{$\begin{array}{c}\text { Kidney homogenate } \\
\text { injected at: }\end{array}$} & $\% \mathrm{PD}^{\mathrm{d}}$ & \multicolumn{3}{c}{ Percentage PD, post-injection } \\
Primary & Challenge & & $1 \mathrm{wk}$ & $2 \mathrm{wk}$ & $3 \mathrm{wk}$ & $4 \mathrm{wk}$ & $5 \mathrm{wk}$ \\
\hline Negative & Negative & $0(0)$ & $0(0)$ & $0(0)$ & $0(0)$ & $0(0)$ & $0(0)$ \\
Positive & Negative & $0(0)$ & $0(0)$ & $0(0)$ & $0(0)$ & $0(0)$ & $0(0)$ \\
Positive & Positive & $0(0)$ & $0(0)$ & $0(0)$ & $0(0)$ & $0(0)$ & $0(0)$ \\
Negative & Positive & $0(50)$ & $20(50)$ & $90(70)$ & $90(80)$ & $40(60)$ & $50(30)$ \\
a Percentage of donor fish with PD at time of removal of kidneys, to test for infectivity 1 or 2 wk post-challenge
\end{tabular}

Table 7 Salmo salar. Percentage of salmon parr (13.9 $\pm 3.2 \mathrm{~g})$ with pancreas disease pathology at various weeks following i.p injection of kidney homogenate taken from non-immune and immune post-smolts (Expt 5), injected at a dose of $30 \mu \mathrm{g} \mathrm{g}^{-1}$ body weight. Results in parentheses are from kidneys taken 2 wk post-challenge. Temperature $14^{\circ} \mathrm{C}$. Ten fish sampled per group per week. E: early PDi C: chronic PD

\begin{tabular}{|c|c|c|c|c|c|c|}
\hline \multicolumn{2}{|c|}{$\begin{array}{l}\text { Kidney homogenate } \\
\text { injected at: }\end{array}$} & \multirow[t]{2}{*}{$\% \mathrm{PD}^{\mathrm{d}}$} & \multicolumn{4}{|c|}{ Percentage PD, post-injection } \\
\hline Primary & Challenge & & $1 \mathrm{wk}$ & $2 w k$ & $3 w k$ & $4 \mathrm{wk}$ \\
\hline Negative & Negative & $0(0)$ & $0(0)$ & $0(0)$ & $0(0)$ & $0(0)$ \\
\hline Positive & Negative & $10(10) \mathrm{C}$ & $0(0)$ & $0(0)$ & $0(0)$ & $0(0)$ \\
\hline Positive & Positive & $10(10) \mathrm{C}$ & $0(0)$ & $0(0)$ & $0(0)$ & $0(0)$ \\
\hline Negative & Positive & $30 \mathrm{E}(60)$ & $0(0)$ & $50 \mathrm{E}(20 \mathrm{E})$ & $50(10)$ & $80(80)$ \\
\hline \multicolumn{2}{|c|}{ Positive control } & & 0 & $40 \mathrm{E}$ & 90 & 70 \\
\hline
\end{tabular}




\section{DISCUSSION}

The present work shows, for the first time, that fish which have recovered from experimentally induced PD develop a very effective level of protection which can be maintained for at least 9 mo. This demonstrates the immunogenicity of the PD agent and potential for development of a vaccine.

McVicar (1990) and Raynard \& Houghton (1993) provided evidence that the causative agent of $\mathrm{PD}$ is probably a virus because of the infectious nature of the disease. Transmission can be achieved by cohabitation or by injection of infective kidney material following filtration through a $0.22 \mu \mathrm{m}$ Millipore filter.

The protection induced following a primary infection of PD is highly significant. Little work has been carried out on protection of fish to viral diseases following primary infection since in many cases, a carrier state is induced following infection (Yamamoto 1975a, Bootland et al. 1991). Piacentini et al. (1989) were able, however, to demonstrate protection in coho salmon Oncorhynchus kisutch to erythrocytic inclusion body syndrome (EIBS) following primary infection and secondary reexposure. Most work has been directed towards development of vaccines using inactivated or cell-cultureattenuated virus but with varying success (Dorson 1988). The more recent approach of sub-unit vaccines using DNA technology looks more promising (Gilmore et al. 1988). In the present study, protection has only been investigated following infection of fish. For a vaccine to PD to be used under field conditions, it could not be administered as a live or even attenuated agent and it is not yet known if inactivation of the agent would induce the same degree of protection as has been demonstrated here following infection. At present, the identification and replication of the protective antigens is hampered because the causative agent cannot be cultured in standard fish cell lines.

The exact nature of the protective response in Atlantic salmon to PD is not yet known but may be due to the production of serum neutralising antibodies. This is currently being investigated. Serum neutralising antibodies to fish viruses have been found to occur in a range of fish species (Knott \& Munro 1986 , Havarstein et al. 1990, Bootland et al. 1991, Vestergaard-Jørgensen et al. 1991). Furthermore, there does appear to be a correlation between increased levels of serum neutralising antibodies and decreased reisolation of virus (Yamamoto 1975b, Mangunwiryo \& Agius 1988). However, the anti-viral property of interferon has not yet been excluded from being involved in protection of salmon to PD. Interferon has been shown to be produced in fish following injection with viral haemorrhagic septicaemia virus (de Kinkelin \& Dorson 1973, de Kinkelin et al. 1982, Renault et al. 1991) and
IPNV (Dorson et al. 1992), and the protective ability of interferon has been demonstrated by de Kinkelin et al. (1982). In these cases, though, interferon appears to be produced early in a viral infection and it is therefore unlikely that the protection exhibited here to PD for up to 9 mo following infection is due to interferon.

The time taken for peak PD pathology to occur appears to be related to temperature. It also coincides with the time expected for the first appearance of antibody from antibody secreting cells (Davidson et al 1992), which is also temperature related. If all the acinar cells are infected and express viral antigen on their surface, then lysis of the cells by antibody and complement may explain the curious synchronous necrosis of all the acinar tissue in PD.

In the present work, no evidence for carrier status was found in fish which had recovered from a primary infection, or in fish immune to the disease, at either 3 , 4 or 7 mo following primary infection and challenge. Primary infected fish showed a high level of recovery, with only $10 \%$ of the fish developing the chronic pancreas pathology described by Munro et al. (1984), namely total absence of pancreas tissue or fibrotic pancreas tissue, with fish becoming progressively thinner. In the present study, kidney homogenates were not made from non-recovered fish alone, so it is not known whether these fish could be carriers. If this is the case, it would contrast with the situation in IPN, where fry which survive an IPN infection, or adults injected with the virus, become asymptomatic carriers showing no clinical signs of the disease or mortality (Yamamoto 1975a, Mangunwiryo \& Agius 1988). These fish have been found to have virus in the kidney, faeces, pyloric caeca and pancreas (Yamamoto 1975a, Bootland et al 1991) and in blood leucocytes (Knott \& Munro 1986 Saint-Jean et al. 1991). Although specific cell types were not examined for the presence of PD agent kidney homogenates would contain several cell types including leucocytes. PD can recur on salmon farms which does, however, suggest that carrier fish may be present within the population. This may be a phenomenon of the intensive and often stressful nature of the industry, which is not reproduced experimentally. In addition, the method employed here of injecting kidney homogenates into parr, although shown to be a good indicator of the infectivity of this material (Raynard \& Houghton 1993), may not be as sensitive as cell culture techniques, and may only detect virus above a certain threshold. However, it is the only method currently available for PD. Nevertheless, the present evidence of immune fish not appearing to exhibit a carrier status strongly suggests that the problems associated with vaccination leading to carrier status may be avoided. Sano et al. (1981) demonstrated that following vaccination of adult rainbow trout Onco- 
rhynchus mykiss with formalin-killed IPNV, virus could not be re-isolated from kidney and spleen of fish with a serum neutralising titre ( $\mathrm{ND}_{50}$ ) above $10^{3}$, whereas virus could be re-isolated from fish with an $\mathrm{ND}_{50}$ less than $10^{3}$. Thus, high neutralising antibody titres appear to be required to overcome the carrier status of IPN.

Since both parr and post-smolts show protection to PD, this demonstrates the possibility for vaccination of parr prior to sea water transfer and subsequent contact with the disease. This was further demonstrated in the groups of fish exposed to a primary infection as parr and a challenge infection following smolting and sea water transfer. Despite the fact that the parr-smolt transformation induced both physiological and stressful changes in salmon (Usher et al. 1991) these did not appear to affect protection to PD.

Acknowledgements. I acknowledge the assistance of the SOAFD Fish Cultivation Unit in the maintenance of the fish and in particular A. Taylor for assistance in sampling. I also thank C. O. Fraser for carrying out the histology and Dr A. H. McVicar for helpful advice. This research was funded by the Scottish Salmon Growers Association and the Highlands and Islands Enterprise.

\section{LITERATURE CITED}

Bootland, L. M., Dobos, P., Stevenson, R. M. W. (1991). The IPNV carrier state and demonstration of vertical transmission in experimentally infected brook trout. Dis. aquat. Org. 10: $13-21$

Davidson, G. A., Ellis, A. E., Secombes, C. J. (1992). An ELISPOT assay for the quantification of specific antibodysecreting cells to Aeromonas salmonicida in rainbow trout, Oncorhynchus mykiss (Walbaum). J. Fish Dis. 15: 85-89

de Kinkelin, P., Dorson, M. (1973). Interferon production in rainbow trout (Salmo gairdneri) experimentally infected with Egtved virus. J. gen. Virol. 19: 125-127

de Kinkelin, P., Dorson, M., Hattenberger-Baudouy, A. M. (1982). Interferon synthesis in trout and carp after viral infection. Dev. comp. Immun. Suppl 2: 167-174

Dorson, $M$. (1988). Vaccination against infectious pancreatic necrosis. In: Ellis, A. E. (ed.) Fish vaccination. Academic Press, London, p. 162-171

Dorson, M., de Kinkelin, P., Torchy, C. (1992). Interferon synthesis in rainbow trout fry following infection with infectious pancreatic necrosis virus. Fish Shellfish Immun. 2: $311-313$

Gilmore, R. D., Engelking, H. M., Manning, D. S., Leong, J. C. (1988). Expression in Escherichia coli of an epitope of the glycoprotein of infectious hematopoietic necrosis virus protects against viral challenge. Bio/Technology 6 : $295-300$

Havarstein, L. S., Endresen, C., Hjeltnes, B., Christie, K. E., Glette, J. (1990). Specific immunoglobulins in serum from Atlantic salmon, Salmo salar L., immunised with Vibrio salmonicida and infectious pancreatic necrosis virus. J. Fish Dis. 13: 101-111
Kent, M. L., Elston, R. A. (1987). Pancreas disease in penreared Atlantic salmon in North America. Bull. Eur. Ass. Fish Pathol. 7: 29-31

Knott, R. M., Munro, A. L. S. (1986). The persistence of infectious pancreatic necrosis virus in Atlantic salmon. Vet. Immun. Immunopath. 12: 359-364

Mangunwiryo, H., Agius, C. (1988). Studies on the carrier state of infectious pancreatic necrosis virus infection in rainbow trout, Salmo gairdneri Richardson. J. Fish Dis. 11: $125-132$

McVicar, A. H. (1987). Pancreas disease of farmed Atlantic salmon, Salmo salar, in Scotland: epidemiology and early pathology. Aquaculture 67: 71-78

McVicar, A. H. (1990). Infection as a primary cause of pancreas disease in farmed Atlantic salmon. Bull. Eur. Ass. Fish Pathol. 10: 84-87

Munro, A. L. S., Ellis, A. E., McVicar, A. H., McLay, H. A. (1984). An exocrine pancreas disease of farmed Atlantic salmon in Scotland. Helgoländer Meeresunters. 37 : $571-586$

Murphy, I M., Rodger, H. D., Drinan, E. M., Gannon, F., Kruse, P., Körting, W. (1992). The sequential pathology of pancreas disease in Atlantic salmon farms in Ireland. J. Fish Dis. 15: 401-408

Piacentini, S. C., Rohovec, J. S., Fryer, J. L. (1989). Epizootiology of erythrocytic inclusion body syndrome. J. Aquat. Anim. Health 1: 173-179

Poppe, T., Rimstad, E., Hyllseth, B. (1989). Pancreas disease in Atlantic salmon (Salmo salar) post-smolts infected with infectious pancreatic necrosis virus (IPNV). Bull. Eur. Ass. Fish Path. 9: 83-85

Raynard, R. S., Houghton, G. (1993). Development towards an experimental protocol for the transmission of pancreas disease of Atlantic salmon Salmo salar. Dis. aquat. Org. 15 $123-128$

Renault, T., Torchy, C., de Kinkelin, P. (1991). Spectrophotometric method for titration of trout interferon, and its application for rainbow trout fry experimentally infected with viral haemorrhagic septicaemia virus. Dis. aquat. Org. 10: $23-29$

Saint-Jean, S. R., Minonido, M. P. V., Palacios, M. A., Prieto, S. P. (1991). Detection of infectious pancreatic necrosis in a carrier population of rainbow trout, Oncorhynchus mykiss (Richardson), by flow cytometry. J. Fish Dis. 14: 545-553

Sano, T., Tanaka, K, Fukuzaki, S. (1981). Immune response in adult trout against formalin killed concentrated IPNV Dev. biol. Stand 49: 63-70

Usher, M. L., Talbot, C., Eddy, F. B. (1991). Effects of transfer to sea water on growth and feeding in Atlantic salmon smolts (Salmo salar). Aquaculture 94: 309-326

Vestergaard-Jørgensen, P. E., Olesen, N. J., Lorenzen, N., Winton, J. R., Ristow, S. S. (1991). Infectious haematopoietic necrosis (IHN): detection of trout antibodies to the causative viruses by means of plaque neutralisation, immunofluorescence, and enzyme-linked immunosorbent assay. J. Aquat. Anim. Health 3: 100-108

Yamamoto, T (1975a). Frequency of detection and survival of infectious pancreatic necrosis virus in a carrier population of brook trout (Salvelinus fontinalis) in a lake. J. Fish. Res. Bd Can. 32: 568-570

Yamamoto, T (1975b). Infectious pancreatic necrosis (IPN) virus carriers and antibody production in a population of rainbow trout (Salmo gairdneri). Can. J. Microbiol. 21. $1343-1347$

Manuscript first received: June 7, 1993

Revised version accepted. December 5, 1993 